\title{
Cellulose sulphuric acid as a biodegradable catalyst for conversion of aryl amines into azides at room temperature under mild conditions
}

\author{
FIROUZEH NEMATI* and ALI ELHAMPOUR \\ Department of Chemistry, Faculty of Science, Semnan University, Semnan 35131-19111, Iran \\ e-mail: fnemati_1350@yahoo.com; fnemati@semnan.ac.ir
}

MS received 7 September 2011; revised 3 December 2011; accepted 16 January 2012

\begin{abstract}
This article describes simple and efficient method for the diazotization and azidation of different aromatic amines over cellulose sulphuric acid, sodium nitrite and sodium azide under mild conditions at room temperature. Various aryl amines possessing electron-withdrawing groups or electron-donating groups have been converted into the corresponding aryl azides with $71-99 \%$ yields. The use of mild reaction conditions, avoids the use of harmful acids and toxic solvents and short reaction times are advantages of this methodology. The selected catalyst is found to be highly efficient and recyclable.
\end{abstract}

Keywords. Cellulose sulphuric acid; aryl azides; diazotization; biodegradable.

\section{Introduction}

Aromatic azides are useful intermediates with various applications in organic and bioorganic chemistry. ${ }^{1}$ Two important applications of these compounds are 1,3dipolar cycloaddition to produce five-membered heterocycles $^{2}$ and their use as phothoaffinity labelling agents for proteins. ${ }^{3}$ Thus, the synthesis of aryl azides is of prime importance.

A number of methods have been developed to synthesis of aryl azides, for example: reaction of $p$-tosyl azide with aryl grignard or lithium reagent derived from the corresponding aryl halides, ${ }^{4}$ reaction of arylamine with $\mathrm{TfN}_{3}, \mathrm{CuSO}_{4}$ and triethylamin, ${ }^{5}$ direct coupling of arylhalides ${ }^{6}$ or arylboronic acides ${ }^{7}$ with $\mathrm{NaN}_{3}$ catalysed by copper salts, and combination of aryl amines with $t$-BuONO followed by addition of $\mathrm{NaN}_{3}$ or $\mathrm{TMSN}_{3}$. Furthermore, $\left[\mathrm{ArN}_{2}\right]\left[\mathrm{BF}_{4}\right]$ salts immobilized in $[\mathrm{bmim}]\left[\mathrm{PF}_{6}\right]$ ionic liquid have been shown to react with $\mathrm{TMSN}_{3}$ to yield the desired azides. ${ }^{8}$ Although there are specific merits to each of these methods, different kinds of drawbacks include long reaction times, highly expensive reagents and use of toxic solvents commonly required. Hence, there is still a considerable interest in developing simple methods for synthesis of arylazides that requires a low manufacturing cost while minimizing environmental pollution are preferable.

Diazonium salts are multipurpose compounds in organic chemistry. However, their poor stability limits their applications. Recently, some methods on the

*For correspondence stabilization of diazonium salts are reported, such as synthesis of stable arenediazonium tosylate salts using $p$ - $\mathrm{TSOH}^{9}$ or application of resin $\mathrm{NO}_{2}^{-}$as nitrite source. ${ }^{10}$ Zarei and co-workers reported the use of grinding of $\mathrm{ArNH}_{2} / \mathrm{SSA} / \mathrm{NaNO}_{2}$ in a mortar for the synthesis of very stable diazunium salts. ${ }^{11}$ The reason for their increased stability of these salts relative to $\mathrm{ArN}_{2}^{+} \mathrm{Cl}^{-}$is that, decomposition of a diazonium salt is dependent on the donor properties of the conjugated anion. ${ }^{12}$ The sulphate anions are less nucleophile than free chloride anions therefore of increasing stabilization in diazonium salt.

Considering the new trends of science and technology towards using natural materials, in addition to the environmental hazards of some current methods, the research efforts on green and eco-friendly methods have become popular and desirable. One of the newly investigated alternatives which could fit in such standards is natural biopolymers and specially cellulose which could be used as a support for sulphuric acid. ${ }^{13}$

\section{Experimental}

Chemicals were purchased from the Fluka, Merck and Aldrich chemical companies. Melting points were determined on Electrothermal 9100 without further corrections. TLC on commercial aluminum-backed plates of silica gel $60 \mathrm{~F} 254$ was used to monitor the progress of reactions. Infrared spectra were recorded on a Shimadzu 8400s spectrometer with $\mathrm{KBr}$ plates. Only representative absorptions are given. NMR spectra were 
taken in $\mathrm{CDCl}_{3}$ on a Bruker Avance3-400 MHz instrument at $20-25^{\circ} \mathrm{C}$.

\subsection{Preparation and recycling of cellulose sulphuric acid}

CSA was prepared according to the procedure of Ahmad Shaabani et al. ${ }^{14}$ The catalyst was recovered by filtration and rinsed with EtOAc and $\mathrm{MeOH}$ thoroughly and dried in vacuum oven at $50^{\circ} \mathrm{C}$ for $24 \mathrm{~h}$ to give recycled CSA. The diazotization-azidation of 4amino benzoic acid was repeated with recycled catalyst. The results indicate that the catalyst was recyclable three times without any significant loss of activity.

\subsection{Experimental procedure for synthesis of 4-azido} benzoic acid

4-Aminobenzoic acid (2 mmol, $0.274 \mathrm{~g}$ ) and CSA $(1.5 \mathrm{~g})$ were charged into a $25 \mathrm{~mL}$ round-bottom flask, then $0.2 \mathrm{~mL}$ of water was added and the mixture was magnetically stirred to afford a homogeneous mixture, subsequently $\mathrm{NaNO}_{2}$ (4 mmol, $0.138 \mathrm{~g}$ ) was added. The reaction mixture was stirred for $5 \mathrm{~min}$. In this period of time the starting amin disappeared. The solution of $\mathrm{NaN}_{3}(5 \mathrm{mmol}, 0.326 \mathrm{~g})$ in $\mathrm{H}_{2} \mathrm{O}(6 \mathrm{ml})$ was added gradually to the diazonium salt and stirring was continued for $5 \mathrm{~min}$. The mixture was diluted with EtOAc $(10 \mathrm{~mL})$ and after vigorous stirring, was filtered. The filtrate was extracted with EtOAc $(3 \times 10 \mathrm{~mL})$ and combined organic layer was treated with $5 \% \mathrm{NaOH}$ solution
$(15 \mathrm{~mL})$ (if a substrate has a carboxyl group, the reaction mixture should be acidified to $\mathrm{pH}=1$ ), then dried over anhyd $\mathrm{Na}_{2} \mathrm{SO}_{4}$. The solvent was evaporated in vacuum and the 4-azidobenzoic acid was obtained as yellow crystalline product with an yield of $99 \%, 0.32 \mathrm{~g}, \mathrm{mp}$ $180^{\circ} \mathrm{C}$. The other products were purified by flash chromatography ( $n$-hexane-EtOAc, 95:5). The most of the products were kept away from direct sunlight.

\subsection{Spectroscopic data}

2.3a Table 1, entry 1: ${ }^{1} \mathrm{H} \mathrm{NMR}\left(\mathrm{CDCl}_{3}, 400 \mathrm{MHz}\right) \delta$ 8.28-8.24 (m, 1H); 7.18-7.14 (m, 1H); IR (KBr, $\left.\mathrm{cm}^{-1}\right)$ : 2129.

$2.3 \mathrm{~b}$ Table 1, entry 10: M. P. $180^{\circ} \mathrm{C} ;{ }^{1} \mathrm{H}$ NMR $\left(\mathrm{CDCl}_{3}, 400 \mathrm{MHz}\right) \delta 8.14(\mathrm{~d}, J=8.4 \mathrm{~Hz}, 1 \mathrm{H}) ; 7.14(\mathrm{~d}$, $J=8.4 \mathrm{~Hz}) ;{ }^{13} \mathrm{CNMR}\left(\mathrm{CDCl}_{3}, 100 \mathrm{MHZ}\right) \delta 167.92$, $149.27,132.24,131.17,129.02$; IR $\left(\mathrm{KBr}, \mathrm{cm}^{-1}\right): 2400$ 3400 as a broad band $(\mathrm{OH}), 2106\left(\mathrm{~N}_{3}\right), 1681(\mathrm{CO})$; Anal. Calcd. for $\mathrm{C}_{7} \mathrm{H}_{5} \mathrm{~N}_{3} \mathrm{O}_{2}: \mathrm{C}, 51.53 ; \mathrm{H}, 3.06 ; \mathrm{N}$, $25.76 \%$, Found: C, 51.59; H, 3.10, N, 25.69\%.

2.3c Table 1, entry 8: ${ }^{1} \mathrm{H} \mathrm{NMR}\left(\mathrm{CDCl}_{3}, 400 \mathrm{MHz}\right)$ $\delta 7.5(\mathrm{~d}, J=3 \mathrm{~Hz}, 1 \mathrm{H}) ; 7.34(\mathrm{dd}, J=8.4 \mathrm{~Hz}, 1 \mathrm{H})$; $7.19(\mathrm{~d}, J=8.4 \mathrm{~Hz}, 1 \mathrm{H}) ;{ }^{13} \mathrm{CNMR}\left(\mathrm{CDCl}_{3}, 100 \mathrm{MHZ}\right)$ $\delta$ 144.1, 133.5, 133.3, 130.7, 130.2, 128.6; IR (KBr, $\mathrm{cm}^{-1}$ ): 2113. Anal. Calcd. for $\mathrm{C}_{6} \mathrm{H}_{3} \mathrm{Cl}_{2} \mathrm{~N}_{3}: \mathrm{C}, 38.29 ; \mathrm{H}$, 1.59 ; N, 22.34\%, Found: C, 38.21; H, 1.64, N, 22.28\%.

Table 1. Azidation of aromatic amines with wet $\mathrm{CSA} / \mathrm{NaNO}_{2} / \mathrm{NaN}_{3}$ (solution in $\mathrm{H}_{2} \mathrm{O}$ ) at room temperature.

\begin{tabular}{lcccc}
\hline Entry & \multicolumn{1}{c}{$\mathrm{ArNH}_{2}^{\mathrm{a}}$} & Product $^{\mathrm{b}}$ & Yield $(\%)^{\mathrm{c}}$ & $\mathrm{IR}\left(\mathrm{KBr}, \mathrm{cm}^{-1}\right)$ \\
\hline 1 & $4-\mathrm{NO}_{2} \mathrm{C}_{6} \mathrm{H}_{4} \mathrm{NH}_{2}$ & $4-\mathrm{NO}_{2} \mathrm{C}_{6} \mathrm{H}_{4} \mathrm{~N}_{3}$ & 87 & $2129^{16}$ \\
2 & $2-\mathrm{NO}_{2} \mathrm{C}_{6} \mathrm{H}_{4} \mathrm{NH}_{2}$ & $2-\mathrm{NO}_{2} \mathrm{C}_{6} \mathrm{H}_{4} \mathrm{~N}_{3}$ & 85 & $2150^{16}$ \\
3 & $4-\mathrm{MeC}_{6} \mathrm{H}_{4} \mathrm{NH}_{2}$ & $4-\mathrm{MeC}_{6} \mathrm{H}_{4} \mathrm{~N}_{3}$ (oily) & 82 & $2130 ; 2106^{6}$ \\
4 & $4-\mathrm{MeOC}_{6} \mathrm{H}_{4} \mathrm{NH}_{2}$ & $4-\mathrm{MeOC}_{6} \mathrm{H}_{4} \mathrm{~N}_{3}$ (oily) & 86 & $2260 ; 2106^{6}$ \\
5 & $2-\mathrm{MeOC}_{6} \mathrm{H}_{4} \mathrm{NH}_{2}$ & $2-\mathrm{MeOC}_{6} \mathrm{H}_{4} \mathrm{~N}_{3}$ & 85 & $2016^{17}$ \\
6 & $4-\mathrm{BrC}_{6} \mathrm{H}_{4} \mathrm{NH}_{2}$ & $4-\mathrm{BrC}_{6} \mathrm{H}_{4} \mathrm{~N}_{3}$ (oily) & 91 & $2249,2291^{6}$ \\
7 & $4-\mathrm{ClC}_{6} \mathrm{H}_{4} \mathrm{NH}_{2}$ & $4-\mathrm{ClC}_{6} \mathrm{H}_{4} \mathrm{~N}_{3}$ (oily) & 83 & $2133 ; 2096^{8}$ \\
8 & $3,4-\mathrm{Cl}_{2} \mathrm{C}_{6} \mathrm{H}_{3} \mathrm{NH}_{2}$ & $3,4-\mathrm{Cl}_{2} \mathrm{C}_{6} \mathrm{H}_{3} \mathrm{~N}_{3}($ oily) & 79 & 2113 \\
9 & $2,4-\mathrm{Cl}_{2} \mathrm{C}_{6} \mathrm{H}_{3} \mathrm{NH}_{2}$ & $2,4-\mathrm{Cl}_{2} \mathrm{C}_{6} \mathrm{H}_{3} \mathrm{~N}_{3}$ & 71 & $2113^{17}$ \\
10 & $4-\mathrm{NH}_{2} \mathrm{C}_{6} \mathrm{H}_{4} \mathrm{COOH}$ & $4-\mathrm{N}_{3} \mathrm{C}_{6} \mathrm{H}_{4} \mathrm{COOH}$ & 99 & 2106 \\
11 & $3-\mathrm{NH}_{2} \mathrm{C}_{6} \mathrm{H}_{4} \mathrm{COOH}$ & $3-\mathrm{N}_{3} \mathrm{C}_{6} \mathrm{H}_{4} \mathrm{COOH}$ & 99 & $2129^{6}$ \\
12 & $2-\mathrm{NH}_{2} \mathrm{C}_{6} \mathrm{H}_{4} \mathrm{COOH}$ & $2-\mathrm{N}_{3} \mathrm{C}_{6} \mathrm{H}_{4} \mathrm{COOH}$ & 93 & $2106^{6}$ \\
13 & $2-\mathrm{C}_{6} \mathrm{H}_{4} \mathrm{NH}_{2}$ & $2-\mathrm{C}_{6} \mathrm{H}_{4} \mathrm{~N}_{3}$ (oily) & 89 & $2125,2088^{16}$ \\
14 & $\mathrm{C}_{6} \mathrm{H}_{5} \mathrm{NH}_{2}$ & $\mathrm{C}_{6} \mathrm{H}_{5} \mathrm{~N}_{3}$ (oily) & 79 & $2101^{8}$ \\
\hline
\end{tabular}

${ }^{\mathrm{a}}$ In the all substrates the time of reactions were between 10 and 15 minutes. ${ }^{\mathrm{b}}$ The products were characterized from their spectral data especially IR, ${ }^{1} \mathrm{H}$ NMR or mp by comparison with reported samples. ${ }^{\mathrm{c}} \mathrm{The}$ yields refer to isolated products 


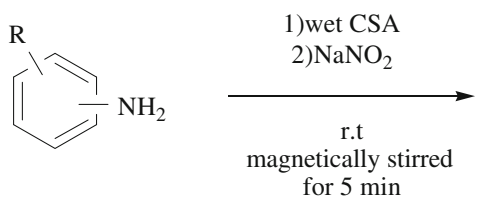

for $5 \mathrm{~min}$

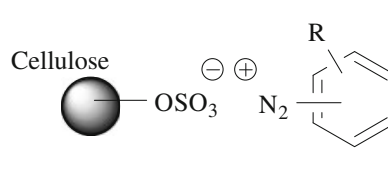

stable diazonium salts

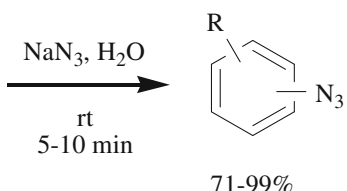

$71-99 \%$

Scheme 1. The synthesis of arylazides under mild condition.

\section{Results and discussion}

As a continuation of our interest in the area of environmentally benign reactions, ${ }^{15}$ we present here the application of green catalyst and simple synthesis of aromatic azides from their corresponding amines using biodegradable and reusable catalyst: cellulose sulphuric acid (scheme 1).

In a model reaction, 4-aminobenzoic acid was homogenized by mixing by CSA and $0.2 \mathrm{~mL}$ of water into a round-bottom flask and magnetically stirred. Then $\mathrm{NaNO}_{2}$ was added, the diazotization, proceeded in few minutes. The amount of water present in the reaction mixture was very important for the successful diazotization. In the absence of water, the most of arylamine was not converted to the corresponding diazonium salt even after longer reaction time. Then, the solution of $\mathrm{NaN}_{3}$ in $\mathrm{H}_{2} \mathrm{O}$ was added to the diazonium salt and thoroughly mixed at room temperature. The reaction proceeded smoothly and rapidly to afford 4-azidobenzoic acid in $99 \%$ yield.

Based on the above results, this process was then extended to other structurally varied amines to investigate its scope and generality. The results are presented in table 1. In contrast to the related SSA procedure, ${ }^{11}$ arylamines including electron-withdrawing groups (e.g., entry 1), electron-rich groups (e.g., entry

Table 2. Reuse of cellulose sulphuric acid for synthesis of 4-azido benzoic acid. ${ }^{\mathrm{a}}$

\begin{tabular}{lcc}
\hline Entry & Use & Yield $^{\mathrm{b}, \mathrm{c}}(\%)$ \\
\hline 1 & 1st & 99 \\
2 & 2nd & 94 \\
3 & 3rd & 87 \\
4 & 4th & 81 \\
5 & 5th & 73 \\
\hline
\end{tabular}

a Reaction condition: first step: 4-aminobenzoic acid ( $2 \mathrm{mmol}, 0.274 \mathrm{~g}$ ), CSA (1.5 g), $0.2 \mathrm{~mL} \mathrm{H}_{2} \mathrm{O}, \mathrm{NaNO}_{2}$ (4 mmol, $0.138 \mathrm{~g})$; second step: $\mathrm{NaN}_{3}$ ( $5 \mathrm{mmol}, 0.326 \mathrm{~g}$ ) in $\mathrm{H}_{2} \mathrm{O}(6 \mathrm{ml})$.

${ }^{\mathrm{b}}$ After each experiment the CSA was recovered and the recovered CSA was used for the subsequent entry of reaction.

${ }^{\mathrm{c}}$ Isolated yield of 4-azido benzoic acid
4) as well as ortho-substituted anilines (e.g., entry 2) were found to react well to give the corresponding arylazides in high yields and no undesirable side reactions, although, the yields and the time of the reaction were dependent on the substituent (table 1). Interestingly, amino benzoic acid derivatives afforded the corresponding azides in excellent yield and did not require further purification.

Our attention was then directed toward the possibility of recycling the catalyst since the recovery and reuse of catalyst are superior for a greener process. After completion of the reaction, the catalyst was recovered as follows: the reaction mixture was extracted with ethyl acetate. The ethyl acetate layer was then dried over sodium sulphate and evaporated under reduced pressure and aromatic azids were purified by flash chromatography. The aqueous layer was filtrate to recover the cellulose sulphuric acid, which its reusability was investigated by using 4-amino benzoic acid as a model substrate. It has been observed that the recovered catalyst was reused three times consecutively with a minimum variation of the yields of the products (table 2). It was observed that with increase in the number of usage of the CSA, its activity is slightly decreased. This could probably be due to the gradual loss of the catalyst during filtration and washing.

It should be noted that the aryldiazonium salts supported on cellulose sulphuric acid were stable to be kept at room temperature and could be stored for $48 \mathrm{~h}$ in a desiccator without any loss of activity.

\section{Conclusions}

In summary, we have established a practical and simple method for the preparation of arylazides. The procedure offers several advantages including high reaction yields, broad application scope and simple experimental process. On the other hand, the selected catalyst is biodegradable, easily available and recyclable. Therefore, the present method is expected to serve as an alternative process for the preparation of arylazide derivatives. 


\section{Supplementary information}

Supplementary data associated with this article can be found in the online version at www.ias.ac.in/chemsci.

\section{Acknowledgement}

We thank the Department of Chemistry and office of gifted student at Semnan University for their financial support.

\section{References}

1. Bräse S, Gil C, Knepper K and Zimmermann V 2005 Angew. Chem., Int. Ed. 445188

2. (a) Rostovsev V V, Green L G, Fokin V V and Sharpless K B 2002 Angew. Chem., Int. Ed. 41 2596; (b) Wang Q, Chan T R, Hilgraf R, Fokin V V, Sharpless K B and Fin M G 2003 J. Am. Chem. Soc. 125 3192; (c) Tornoe C W, Christensen C and Meldal M J 2002 Org. Chem. 67 3057; (d) Avemaria F, Zimmermann V and Braese S 2004 Synlett 7 1163; (e) Lu B, Xie X A, Zhu J D and Ma D W 2005 Chin. J. Chem. 23 1637; (f) Lucas R L, Powell D R and Borovik A S $2005 \mathrm{~J}$. Am. Chem. Soc. 127 11596; (g) Bart S C, Lobkovsky E, Bill E and Chirik P J 2006 J. Am. Chem. Soc. 1285302

3. (a) Gartner C A 2003 Curr. Med. Chem. 10 671; (b) Peng Q, Qu F Q, Xia Y, Zhou J H, Wu Q Y and Peng L 2005 Chin. Chem. Lett. 16 349; (c) Kuse M, Doi I, Kondo N, Kageyama Y and Isobe M 2005 Tetrahedron 61 5754; (d) Han S Y, Park S S, Lee W G, Min Y K and Kim B T 2006 Bioorg. Med. Chem. Lett. 16 129; (e) Rizk M S, Shi X and Platz M S 2006 Biochemistry 45543
4. (a) Gavenonis J and Tilley T D $2002 \mathrm{~J}$. Am. Chem. Soc. 124 8536, (b) Gavenonis J and Tilley T D 2002 Organometallics 215549

5. Liu Q and Tor Y 2003 Org. Lett. 52571

6. Zhu W and Ma D 2004 Chem. Commun. 7888

7. Tao C Z, Cui X, Li J, Liu A X, Liu L and Guo Q X 2007 Tetrahedron Lett. 483525

8. Hubbard A, Okazaki T and Laali K K 2008 J. Org. Chem. 73316

9. Lee Y M, Moon M E, Vajpayee V, Filimonov V D and Chi K-W 2010 Tetrahedron $\mathbf{6 6} 7418$

10. Trusova M E, Krasnokutskaya E A, Postnikov P S, Choi Y, Chi K-W and Filimonov V D 2011 Synthesis 13 2154

11. Zarei A, Hajipour A R, Khazdooz L and Aghaei H 2009 Tetrahedron Lett. 504443

12. Zollinger H 1994 In: Diazo chemistry I, Aromatic and Heteroaromatic compounds, New York, NY (USA): VCH publishers pp. 25

13. (a) Alinezhad H and Tollabian Z 2010 Bull. Korean Chem. Soc. 31 1927; (b) Safari J, Banitaba S H and Khalili S D 2011 J. Mol. Catal. A: Chem. 335 46; (c) Shaabani A, Seyyedhamzeh M, Maleki A and Rezazadeh F 2009 Appl. Catal. A 358146

14. Shaabani A, Rahmati A and Badri Z 2008 Catal. Commun. 913

15. (a) Nemati F, Kiani H and Hayeniaz Y S 2011 Synthetic Commun. 41 2985; (b) Nemati F and Kiani H 2010 Chin. Chem. Lett. 21 403; (c) Nemati F, Bigdeli M A, Mahdavinia G H and Kiani H 2010 Green Chem. Lett. 3 89; (d) Nemati F, Fakhaei A S, Amoozadeh A and Hayeniaz Y S 2011 Synthetic Commun. 413695

16. Zarchi M A K, Nabaei R and Barani S 2012 J. Appl. Poly. Sci. 123 788. doi: 10.1002/app.34515

17. Hu M, Li J and Yao S Q 2008 Org. Lett. 105529 